\title{
Podatek od kart do gry w polskim prawie skarbowym
}

I. Istnieje wiele teorii na temat okoliczności i miejsca narodzin kart do gry. W literaturze przedmiotu wskazuje się, że gra w karty wywodzi się z czternastowiecznych koreańskich strzał służących do wróżb. Wynalezienie tej niezwykle popularnej formy gier hazardowych przypisuje się również Chińczykom, którzy mieli grać w karty już w XII w., oraz Hindusom ${ }^{1}$. Niezależnie od tego, w jaki sposób karty do gry dotarły do Europy faktem jest, że już w XIV w. była to rozrywka znana we Włoszech, Francji, Hiszpanii, Niemczech i Szwajcarii ${ }^{2}$. Warto również dodać, że pierwsza wzmianka na temat kart do gry w Polsce - lakoniczny zakaz ich używania - pochodzi z $1456 \mathrm{r}$. i wiąże się ze środowiskiem krakowskiej uczelni ${ }^{3}$.

Pomimo licznych zakazów oraz głosów gorliwych kaznodziei, którzy potępiali karciarzy, nowa forma hazardu cieszyła się w Polsce coraz większą popularnością ${ }^{4}$. Nie powinien zatem dziwić fakt, że stosunkowo wcześnie zaczęto poszukiwać możliwości czerpania przez państwo dochodów z nieodpartej ludzkiej skłonności do tego rodzaju gier ${ }^{5}$. Celem niniejszego opracowania jest przedstawienie podatku od kart do gry, czyli daniny, która funkcjonowała w systemie polskiej skarbowości przez prawie 150 lat. Należy przy tym podkreślić, że opodatkowania kart do gry nie można utożsamiać z opodatkowa-

\footnotetext{
${ }^{1}$ Szerzej zob. D.G. Schwartz, Historia hazardu, Warszawa 2009, s. 55 i n.

2 Ibidem, s. 62.

${ }^{3}$ Zob. A. Harmeliński-Dzierożyński, O kartach, karciarzach, grach poczciwych i grach szulerskich. Szkice obyczajowe z wieków XV-XIX, Kraków 1976, s. 8. Zob. także A. Prochaska, Przyczynek do dziejów gry w karty w Polsce, „Kwartalnik Historyczny” 1894, t. 8, s. 443-445.

${ }^{4}$ T. Ujazdowski w 1827 r. napisał: „Za panowania Zygmunta III iuż gorliwi kaznodzieje powstawali przeciw kartownikom; iednak za panowania obudwoch Sasów naywięcéy weszły w używanie, - wiele familiy pogrążyły w nieszczęściu, ludzi zaś nikczemnych w maiątki i bogactwa zaopatrzyły!” T. Ujazdowski, Karty polskie do grania, „Monitor Warszawski” 1827, No 18, s. 87.

${ }^{5} \mathrm{~W}$ instruktarzu celnym z 1643 r. wśród towarów objętych cłem wymienia się: „Karty do gry Flamskie, Francuskie, Noremberskie etc.” Zob. Instruktarz od których towaróow do Korony prowadzonych, placić maia podatek Rzpltey należacy, ab inductismercibus, miasto czwartego grosza, po kopie od sta złotych, Volumina Legum. Przedruk zbioru praw staraniem XX. Pijarów w Warszawie, od roku 1732 do roku 1782, wydanego, t. IV, Petersburg 1860, s. 42.
} 
niem urządzania gier w karty. Gry w karty, jako zinstytucjonalizowana forma hazardu, czyli forma umożliwiająca czerpanie zysku z gry przez osobę postronną, pojawiły się w Polsce dopiero w latach 70. dwudziestego wieku ${ }^{6}$, natomiast odrębne przepisy dotyczące opodatkowania tego rodzaju gier zostały wydane w $1991 \mathrm{r}^{7}$

II. Opodatkowanie kart do gry zostało wprowadzone do polskiego systemu prawnego w ramach reform podatkowych $\mathrm{z}$ lat 1775-1776, których podstawowym celem było zwiększenie dochodów skarbowych ${ }^{8}$. Przyjęta w 1775 r. ustawa nosiła nazwę ,papieru stemplowanego”, w istocie normowała jednak cztery rodzaje danin, tj.: podatek stemplowy od umów prywatnoprawnych, opłatę skarbową, tzw. taksy oraz podatki od kart do gry, kalendarzy i ksiąg żydowskich. Wspólną cechą powyższych należności był sposób ich poboru w formie stempla na dokumencie, przedmiocie, bądź też stempla wydrukowanego na papierze ${ }^{9}$. Podatek od kart do gry, podobnie jak inne podatki obrotowe, historycznie związany jest więc z opłatami skarbowymi. Nie była to jednak opłata w ujęciu teoretycznym, gdyż pobór tej daniny nie był związany z wykonywaniem czynności urzędowych lub usług publicznych na rzecz zainteresowanego.

Konstytucja sejmowa z 1775 r. stanowiła: „Tym samym stemplem karty do gry Polskie y Francuzkie, wszelkiego gatunku naznaczone bydź powinny, a za ten stępel, od kart Polskich, po gr. sr. 2. Od kart zaś Francuzkich, po złotemu płacić się będzie"10. Przedmiotem opodatkowania była zatem talia kart do gry jako całość, natomiast stawki miały postać stałych stawek kwotowych i wynosiły 2 grosze srebrne od talii kart polskich i 1 zł od talii kart francuskich, które oczywiście uchodziły za bardziej wyrafinowane i luksusowe ${ }^{11}$.

\footnotetext{
${ }^{6}$ Hazardowe gry w karty zaczętooficjalnie organizować na promach przedsiębiorstwa państwowego Polska Żegluga Bałtycka. Szerzej zob. L. Palczyński, Gry losowe, „Finanse” 1980, nr 7, s. 27. W 1980 r. wprowadzono do polskiego systemu prawego przepis stanowiący, że za gry losowe uznaje się także takie gry w karty, w których uczestnicy gry grają przeciwko prowadzącemu grę. Zob. rozporządzenie Ministra Finansów z dnia 28 czerwca 1980 r. zmieniające rozporządzenie w sprawie szczegółowych zasad prowadzenia gier losowych i totalizatorów (Dz. U. Nr 15, poz. 53).

${ }^{7}$ Rozporządzenie Ministra Finansów z dnia 17 kwietnia 1991 r. w sprawie stawek podatku obrotowego od jednostek gospodarki uspołecznionej oraz ulg i zwolnień od tego podatku (Dz. U. $\mathrm{Nr}$ 38, poz. 166) oraz rozporządzenie Ministra Finansów z dnia 17 kwietnia 1991 r. w sprawie stawek podatku obrotowego od osób fizycznych oraz nie będących jednostkami gospodarki uspołecznionej osób prawnych i innych jednostek organizacyjnych nie posiadających osobowości prawnej, ulg, zwolnień i trybu płatności tego podatku (Dz. U. Nr 38, poz. 165).

${ }^{8}$ Szerzej zob. R. Rybarski, Skarbowość Polski w dobie rozbiorów, Kraków 1937, s. 22 i n.

${ }^{9}$ Ibidem, s. 12-13.

${ }^{10}$ Volumina Legum. Przedruk zbioru praw staraniem XX. Pijarów w Warszawie, od roku 1732 do roku 1782, wydanego, t. VIII, Petersburg 1860, s. 94.

${ }^{11}$ Ł. Gołębiowski pisał: „Dawni Polacy snać nie przyjęli kart francuzkich, we wszystkiém zachować pragnąć narodowość, chcieli mieć własne”. Ł. Gołębiowski, Gry i zabawy różnych stanów w kraju całym, lub niektórych tylko prowincyach, Warszawa 1831, s. 41.
} 
Warto dodać, że kartami francuskimi w rozumieniu konstytucji z 1775 r. były $\mathrm{w}$ istocie karty typu francuskiego ${ }^{12}$, które mogły być wytwarzane zarówno na terytorium Rzeczypospolitej, jak i za granicą. Przez karty polskie należy natomiast rozumieć karty pisane przez renesansowych rzemieślników polskich, według swoistego wzoru ${ }^{13}$. Konsekwencją wejścia w życie ustawy o papierze stemplowanym był zakaz posiadania i używania kart do gry bez stempla, zaś karty sprowadzane z zagranicy miały być stemplowane w tzw. komorach pogranicznych, których nie wolno było omijać ${ }^{14}$.

W klasycznej doktrynie skarbowości podatek od kart do gry zaliczano do szczególnej kategorii podatków od obrotu, tj. podatków od spekulacji i gry ${ }^{15}$. Niewątpliwie był to podatek obrotowy, należy jednak podkreślić, że przedmiotem opodatkowania nie było urządzanie gier w karty, lecz sama talia kart, zaś obowiązek podatkowy powstawał z chwilą wprowadzenia tej talii do obrotu. Osiemnastowieczny podatek od kart do gry miał jednocześnie cechy podatku od konsumpcji, a biorąc pod uwagę przeznaczenie i dostępność kart w ówczesnych czasach, można nawet stwierdzić, że konsumpcji luksusowej czy zbytkowej ${ }^{16}$.

W 1789 r., na mocy konstytucji zatytułowanej „Pomnożenie dochodu z papieru stęplowanego" dokonano istotnej podwyżki stawek podatku od kart do gry ${ }^{17}$. Od tego roku stawka podatku od kart polskich wynosiła $1 \mathrm{zl}$, natomiast od kart francuskich 2 zl, przy czym w odniesieniu do kart produkowanych i sprowadzanych z zagranicy stosowano dwukrotność stawki. Celem ustawy było zwiększenie wpływów skarbu w związku z powiększeniem armii. Niestety podwyżka stawek nie przełożyła się na wzrost dochodów z tego źródła ${ }^{18}$, niemniej jednak należy zaznaczyć, że w okresie I Rzeczypospolitej dochody skarbu z tytułu podatku od kart do gry wynosiły kilkadziesiąt tysięcy złotych rocznie, co w ówczesnych warunkach było kwotą nie bez znaczenia ${ }^{19}$.

Okres po $1795 \mathrm{r}$. to czas funkcjonowania na ziemiach polskich systemów skarbowych państw zaborczych. Pomimo tego, że na terytorium dawnej Rzeczypospolitej istniały, zwłaszcza w początkach dziejów porozbiorowych,

${ }^{12} \mathrm{~W}$ piśmiennictwie przyjmuje się, że to Francuzi w XV w. zaprojektowali taką talię, jaka używana jest do dnia dzisiejszego. Szerzej na temat kart francuskich zob. D.G. Schwartz, op. cit., s. $70 \mathrm{i} \mathrm{n.}$

${ }^{13}$ Talie kart polskich były składały się z 36 kart, zaś talia francuska, która upowszechniła się w połowie XVIII w. miała 52 karty. Szerzej na temat różnic między kartami polskimi i francuskimi w XVIII w. zob. A. Hermeliński-Dzierożyński, op. cit, s. 30 i n.

${ }^{14}$ Zob. R. Rybarski, Skarbowość Polski..., s. 197.

${ }^{15}$ Zob. S. Głąbiński, Nauka skarbowości z dodatkiem o skarbowości Austryi i Galicyi, Lwów 1911, s. 460.

${ }^{16}$ Tamże, s. 460 i 531 oraz R. Rybarski, Skarbowość Polski..., s. 13.

${ }^{17}$ VL, t. IX, s. 67-68.

${ }^{18}$ Zob. R. Rybarski, Skarbowość Polski..., s. 205.

${ }^{19}$ Szerzej na temat wpływów z tego źródła w latach 1776-1793 zob. M. Drozdowski, Podstawy finansowe działalności państwowej w Polsce 1764-1793, s. 108-111, 154 i 170. 
pewne odrębne urządzenia $\mathrm{i}$ instytucje finansowe $\mathrm{e}^{20}$, o polskich przepisach skarbowych dotyczących podatku od kart do gry można mówić jedynie w odniesieniu do Księstwa Warszawskiego oraz Królestwa Polskiego.

W Księstwie Warszawskim opłaty stemplowe obowiązywały na mocy konstytucji sejmowej z 1775 r. i zmian dokonanych przez Prusy w okresie zaborów $^{21}$. Podobnie jak w okresie I Rzeczypospolitej przepisy o opłatach stemplowych normowały $\mathrm{w}$ istocie różne podatki i opłaty o takim samym sposobie ich poboru, w tym podatek od kart do gry. Dochody z tytułu podatku od kart do gry były kwalifikowane jako wpływy z podatków niestałych ${ }^{22}$, natomiast stemplowaniem i dystrybucją kart zajmowało się podlegające ministrowi finansów i skarbu główne biuro stemplowe w Warszawie ${ }^{23}$.

Istotne zmiany w konstrukcji analizowanej daniny wprowadziła dopiero ustawa Prawo o opłatach stemplowych z 1811 r. $^{24}$, która obowiązywała bez większych zmian przez cały okres Królestwa Kongresowego ${ }^{25}$. Zgodnie z jej przepisami podatek stemplowy był pobierany ze sprzedaży materiałów stemplowych, w tym kart do gry. Co szczególnie istotne, ustawa nie przewidywała stawek podatkowych, natomiast wskazywała ceny stempla na kartach, które były jednocześnie ceną sprzedaży kart ${ }^{26}$. Wysokość owych cen była uzależniona od typu kart oraz jakości poszczególnych taliii ${ }^{27}$. Warto dodać, że nadal wyróżniano karty polskie i francuskie, a także taroki i traplie (trefle) ${ }^{28}$. Karty były wytwarzane tylko w jednej fabryce, która była wprawdzie własnością prywatną, lecz której właściciel nie miał prawa sprzedaży kart osobom trzecim.

${ }^{20}$ Zob. J. Rutkowski, Historia gospodarcza Polski, t. II, Czasy porozbiorowe do 1918 roku, Poznań 1950, s. 203.

${ }^{21}$ Zob. A. Komar, Polityka podatkowa rzadu pruskiego $w$ Wielkim Księstwie Poznańskim w latach 1815-1870. Studia i Materiały do Dziejów Wielkopolski i Pomorza, t. VI, z. 2, 1961, s. 128.

${ }^{22}$ Zob. dekret z dnia 24 marca 1809 r. Wstęp do Prawa o Poborach, Dziennik Praw Księstwa Warszawskiego 1810, t. 1, Nr 10, s. 243. W doktrynie zwraca się uwagę, że według klasyfikacji przyjętej w ówczesnym systemie budżetowym podatkami niestałymi zwane były podatki pośrednie. Zob. Z. Stankiewicz, Królestwo Polskie 1815-1863, [w:] Historia państwa i prawa Polski, t. III, Od rozbiorów do uwłaszczenia, red. J. Bardach, M. Senkowska-Gluck, Warszawa 1981, s. 373.

${ }^{23}$ Zob. dekret z dnia 16 lutego 1808 r. o utworzeniu przy ministrze finansów i skarbu głównego biura stemplowego, jego organizacji kompetencjach i uposażeniu pracowników, [w:] Ustawodawstwo Księstwa Warszawskiego. Akty normatywne władzy najwyższej, t. I, 1807-1808, oprac. W. Bartel, J. Kosim, W. Rostocki, Warszawa 1964, s. 32.

${ }^{24}$ Ustawa z dnia 11 (23) grudnia 1811 r. Prawo o opłatach stęplowych, Dziennik Praw Księstwa Warszawskiego 1811, t. 4, Nr 38, s. 47 i n., dalej jako: Prawo o opłatach stemplowych.

${ }^{25}$ Zob. H. Radziszewski, Skarb i Organizacya Władz Skarbowych w Królestwie Polskiem, t. I, (1815-1830), Warszawa 1907, s. 97.

${ }^{26}$ Do 1841 r. stempel do kart do gry wyrażał orła krajowego, zaś cena wyznaczona była w zł. Od 1841 r. na kartach umieszczano herb Cesarstwa, natomiast ceny wyrażane były w rublach i kopiejkach. Zob. ukaz Carsko-Królewski z dnia 3 (15) września 1841 r., Dziennik Praw Królestwa Polskiego, t. 23, Nr 92, s. 42.

27 § 17 Prawa o opłatach stemplowych.

${ }^{28}$ Tarok to 'dawna gra w karty, do której używa się 78 kart z 7 królami', Słownik języka polskiego, red. W. Doroszewski, http://doroszewski.pwn.pl/haslo/tarok. 
Wszystkie karty do gry nabywał skarb państwa, który następnie wprowadzał je do obrotu, a różnica pomiędzy ceną, za jaką skarb nabywał karty od producenta, a ceną ich sprzedaży na rzecz osób trzecich stanowiła dochód skarbu ${ }^{29}$. Stawkę kwotową, w wysokości 6 złp od talii, stosowano wyłącznie w odniesieniu do kart sprowadzanych z zagranicy, przy czym importer był zobowiązany do uzyskania odrębnego zezwolenia ministra skarbu ${ }^{30}$. Tym samym, dawny jednofazowy podatek obrotowy od kart do gry przybrał formę częściowego, gdyż obejmującego jedynie handel, monopolu fiskalnego państwa ${ }^{31}$. Od 1852 r. monopol skarbowy został zastąpiony przez indemnizację ze skarbu Cesarstwa za dochód ze sprzedaży kart do gry. Rzeczona indemnizacja była zaliczana w ramach opłat stemplowych - do dochodów niestałych Królestwa ${ }^{32}$.

III. Po odzyskaniu niepodległości w 1918 r. w Polsce funkcjonowało 9 zupełnie odrębnych systemów skarbowych, a podstawowym zadaniem, z jakim musiały się zmierzyć władze odrodzonego państwa była unifikacja prawodawstwa skarbowego. Proces ujednolicania prawa skarbowego przebiegał dwuetapowo. W pierwszej kolejności zunifikowano systemy podatkowe wewnątrz każdej dzielnicy. Następnie rozpoczęto ujednolicanie prawa między poszczególnymi dzielnicami ${ }^{33}$. Istotną rolę w dziele unifikacji prawa skarbowego odegrały również organy autonomicznego województwa śląskiego.

Podatek od kart do gry został wprowadzony do systemu prawnego II Rzeczypospolitej w drodze ustawy z 6 lipca 1920 r. w przedmiocie opłaty stemplowej od kart do gry ${ }^{34}$, której moc obowiązującą rozciągnięto następnie na obszar ziemi wileńskiej oraz województw nowogródzkiego, poleskiego i wołyńskiego $^{35}$. Rozwiązania przyjęte w ustawie z 1920 r. bezpośrednio nawiązywały do osiemnastowiecznego pierwowzoru tej daniny, jak również do kon-

${ }^{29}$ Zob. H. Radziszewski, Skarb i Organizacya..., s. 99.

${ }^{30}$ Import kart z zagranicy bez zezwolenia ministra skarbu, jak również używanie kart nieostemplowanych zagrożone były sankcją finansową w wysokości 20 złp od talii, również pobieraną w formie stempla. Zob. § 21 Prawa o opłatach stemplowych.

${ }^{31} \mathrm{~W}$ literaturze historycznoprawnej wskazuje się, że państwu przysługiwało regale kart do gry. Zob. K. Grzybowski, Historia państwa i prawa Polski, t. IV, Od uwłaszczenia do odrodzenia państwa, Warszawa 1982, s. 205.

32 Zob. J. Bloch, Finanse Kr. Polskiego za cały czas istnienia skarbu Królestwa od d. 1 Czerwca 1815 do 31 Grudnia 1866 r. Zarząd, wladze skarbowe i reforma podatkowa w Królestwie Polskiem, Warszawa 1883, s. 6-10.

33 Szerzej zob. E. Taylor, Polityka skarbowa i system podatkowy Rzeczypospolitej Polskiej, Poznań 1929, s. 8 i n.; Z. Landau, Skarbowość polska w latach 1918-1920, „Finanse” 1966, nr 2, s. 18-29.

${ }^{34}$ Ustawa z dnia 6 lipca 1920 r. w przedmiocie opłaty stemplowej od kart do gry (Dz. U. RP $\mathrm{Nr}$ 101, poz. 666), dalej jako: ustawa w przedmiocie opłaty stemplowej od kart do gry z $1920 \mathrm{r}$.

${ }^{35}$ Zob. rozporządzenie Rady Ministrów z dnia 2 czerwca 1921 r. w przedmiocie rozciągnięcia mocy obowiązującej ustaw z dnia 6 lipca 1920 r. i z dnia 18 marca 1921 r. o opłacie stemplowej od kart do gry na województwa nowogródzkie, poleskie i wołyńskie oraz powiaty grodzieński, białowieski i wołkowyski województwa białostockiego (Dz. U. RP Nr 55, poz. 342) oraz rozporządzenie 
strukcji funkcjonujących w prawodawstwie dawnych państw zaborczych, tj. Austrii i Prus ${ }^{36}$. W państwach tych karty do gry podlegały bowiem odrębnej daninie o cechach podatku pośredniego (w Austrii określanego mianem opłaty) pobieranego w formie stempla ${ }^{37}$, podczas gdy w byłym zaborze rosyjskim wyrób kart do gry był objęty monopolem państwowego Zarządu Zakładów Dobroczynnych Cesarzowej Marii ${ }^{38}$.

Pomimo tego, że w doktrynie skarbowości istniała communis opinio co do podatkowego charakteru tzw. opłaty od kart do gry, w tytule ustawy posłużono się określeniem opłata stemplowa, a wpływy z tego źródła były zaliczane do wpływów z opłat. Warto natomiast zwrócić uwagę, że w akcie z 1920 r. nie przewidziano zróżnicowania wysokości stawek w zależności od typu kart. Nie było takiej potrzeby, gdyż karty polskie wyszły z użycia w XIX w., a rynek zdominowały dawne karty francuskie ${ }^{39}$. W związku z powyższym w przepisach wykonawczych doprecyzowano, że opłacie stemplowej podlegają wszelkie karty, których można użyć do gry, bez względu na ich formę ${ }^{40}$.

Skala podatku od kart do gry miała charakter proporcjonalny, natomiast stawka była kwotowa i początkowo wynosiła 30 marek polskich (mkp) od talii ${ }^{41}$. W marcu 1921 r. podwyższono ją do wysokości $60 \mathrm{mkp}^{42}$, a rok później - na

Ministra Skarbu z dnia 21 sierpnia 1922 r. w przedmiocie rozciągnięcia na obszar Ziemi Wileńskiej mocy obowiązującej ustaw o opłacie stemplowej od kart do gry (Dz. U. RP Nr 74, poz. 673).

${ }^{36} \mathrm{~W}$ Austrii podatek od kart do gry w formie stempla na pierwszej karcie wprowadzono już w XVII w. Szerzej zob. S. Głąbiński, Nauka skarbowości z dodatkiem ..., s. 612 i 629-630. W dzielnicy pruskiej obowiązywał system skarbowy Rzeszy Niemieckiej i Prus, przy czym pierwszy z nich opierał się m.in. na dochodach z podatków pośrednich, w tym akcyzy od kart do gry. Zob. E. Taylor, Polityka skarbowa..., s. 7.

${ }^{37} \mathrm{~W}$ byłym zaborze austriackim podatek od kart do gry funkcjonował na mocy ustawy z $1881 \mathrm{r}$. Obowiązek podatkowy ciążył na producentach i importerach kart, zaś stawki były kwotowe i uzależnione od liczby kart w talii. Stawki w podwójnej wysokości pobierano od kart lakierowanych lub zmywalnych, czyli wyjątkowo trwałych. W byłej dzielnicy pruskiej podatek od kart do gry pobierano na podstawie ustawy z 1878 r. Również w tym wypadku opodatkowaniu podlegały produkcja i import kart, zaś wysokość stawek była uzależniona od ich liczby w talii. Szerzej zob. E. Taylor, Prawo skarbowe Rzeczypospolitej Polskiej, cz. II, Poznań 1920, s. 25-26 i 37.

${ }^{38} \mathrm{~W}$ czasie okupacji niemieckiej wprowadzono koncesjonowany wyrób kart do gry, przy czym karty przed dopuszczeniem do obrotu musiały być zaopatrzone w stempel, za który uiszczało się należność w kwocie 80 fen. od talii. Szerzej zob. E. Taylor, Prawo skarbowe..., s. 15. Zob. także E. Strasburger, Ustrój skarbowy Rzeczpospolitej Polskiej, Warszawa 1922, s. 41.

${ }^{39}$ Szerzej zob. A. Hermeliński-Dzierożyński, op. cit., s. 37 i n.

${ }^{40} \S 1$ rozporządzenia Ministra Skarbu z dnia 31 października 1920 r. celem wykonania - na obszarze b. dzielnic rosyjskiej i austrjackiej - ustawy z dnia 6 lipca 1920 r. (Dz. Ust. No 101, poz. 666) w przedmiocie opłaty stemplowej od kart do gry (Dz. U. RP Nr 101, poz. 619), dalej jako: rozp. MS z 31.10.1920 r. Powołany przepis obowiązywał również w byłej dzielnicy pruskiej. Zob. rozporządzenie Ministra byłej Dzielnicy Pruskiej rozciągające moc obowiązującą rozporządzenia Ministra Skarbu celem wykonania ustawy z dnia 6 lipca 1920 r. w przedmiocie opłaty stemplowej od kart do gry na b. dzielnicę pruską (Dz. U. RP Nr 104, poz. 691).

${ }^{41}$ Art. 1 ustawy w przedmiocie opłaty stemplowej od kart do gry z 1920 r.

${ }^{42}$ Art. 1 ustawy z dnia 18 marca 1921 r. w przedmiocie opłaty stemplowej od kart do gry (Dz. U. RP Nr 35, poz. 204). 
skutek panującej hiperinflacji - do kwoty $300 \mathrm{mkp}^{43}$. W marcu $1923 \mathrm{r}$. stawka tzw. opłaty stemplowej od kart do gry wynosiła już $100000 \mathrm{mkp}^{44}$. W lutym 1924 r., w związku z reformą walutową, zastosowano do niej stałą jednostkę, przeliczając $100000 \mathrm{mkp}$ na 0,5 franka złotego $0^{45}$. Podatek wpłacany był w tej sumie marek polskich, jaka wynikała z pomnożenia stawki określonej we frankach złotych przez kurs franka obowiązujący w dniu uiszczenia opłaty ${ }^{46}$. Należy również zwrócić uwagę, że od lipca 1924 r. od kart do gry pobierana była dodatkowa opłata na rzecz Polskiego Towarzystwa Czerwonego Krzyża w wysokości 50\% podatku naliczanego od każdej talii. Opłatę uiszczano zarówno od kart sporządzonych w kraju, jak i przywiezionych z zagranicy równocześnie z podatkiem, a dochód z tego tytułu przekazywany był przez Skarb Państwa Polskiemu Towarzystwu Czerwonego Krzyża ${ }^{47}$.

Ze względów fiskalnych działalność gospodarcza w zakresie produkcji oraz handlu kartami do gry podlegała szczególnemu nadzorowi organów skarbowych. Władzom skarbowym przyznano także prawo sprawowania dozoru nad grą w karty w stowarzyszeniach oraz w tych restauracjach, kawiarniach $\mathrm{i}$ innych lokalach publicznych, w których gra w karty była dozwolo$n^{48}$. Z treścią powyższych przepisów korespondował zakaz sprzedaży kart do gry w handlu obnośnym, a także zakaz wszelkiej sprzedaży kart luźnych, nieopakowanych i używanych ${ }^{49}$. Wyrób i sprzedaż kart do gry mogły się odbywać wyłącznie na podstawie zezwolenia wydanego przez organy skarbo$\mathrm{we}^{50}$, w miejscowości wymienionej w tym zezwoleniu i w lokalu uznanym za odpowiedni przez władzę skarbową ${ }^{51}$. Przedsiębiorcy byli zobowiązani do prowadzenia odpowiedniej dokumentacji, a organom podatkowym przysługiwało w każdej chwili prawo wstępu do lokalu wytwórni lub sprzedaży kart,

${ }^{43}$ Art. 3 ustawy z dnia 7 kwietnia 1922 r. w przedmiocie podwyższenia i zrównania stawek przy niektórych opłatach stemplowych (należytościach) (Dz. U. RP Nr 38, poz. 315).

${ }^{44} \S 2$ rozporządzenia Ministra Skarbu w porozumieniu z Ministrem Przemysłu i Handlu z dnia 31 października 1923 r. o dalszem podwyższaniu opłaty stemplowej od kart do gry (Dz. U. RP Nr 127, poz. 1047).

${ }^{45}$ Ustawa z dnia 6 grudnia 1923 r. o zastosowaniu stałej jednostki do obliczania danin, niektórych innych dochodów publicznych oraz kredytów, udzielanych przez instytucje państwowe i samorządowe (Dz. U. RP Nr 127, poz. 1044). Szerzej na temat problemów związanych z jednostką obliczeniową w okresie poprzedzającym reformę walutową zob. Z. Karpiński, Ustroje pieniężne w Polsce od roku 1917, Warszawa 1968, s. 50 i n.

46 § 1 i 2 rozporządzenia Ministra Skarbu w porozumieniu z Ministrem Przemysłu i Handlu z dnia 25 lutego 1924 r. w sprawie zastosowania stałej jednostki do opłaty stemplowej od kart do gry (Dz. U. RP Nr 28, poz. 279).

${ }^{47}$ Art. 1-3 ustawy z dnia 6 czerwca 1924 r. o opłacie od kart do gry na rzecz Polskiego Towarzystwa Czerwonego Krzyża (Dz. U. RP Nr 56, poz. 561).

${ }^{48}$ Art. 6 ustawy w przedmiocie opłaty stemplowej od kart do gry z 1920 r.

${ }^{49}$ Art. 4 i 5 ustawy w przedmiocie opłaty stemplowej od kart do gry z $1920 \mathrm{r}$.

${ }^{50}$ Obowiązek uzyskania zezwolenia wydanego przez Ministerstwo Skarbu był niezależny od obowiązków wynikających z ustaw przemysłowych.

${ }^{51} \S 5$ i 27 rozp. MS z 31.10.1920 r. 
jak również do stowarzyszeń, restauracji, kawiarni i innych lokali, w których odbywała się gra w karty ${ }^{52}$.

Dowodem uiszczenia bądź odroczenia zapłaty podatku był stempel urzędowy oraz banderola ${ }^{53}$. Wytwórca przed wprowadzeniem kart do obrotu zobowiązany był do przedłożenia w kasie urzędu powołanego do stemplowania deklaracji i wpłacenia kwoty podatku ${ }^{54}$, natomiast samo stemplowanie kart to gry - uprzednio opakowanych i zamkniętych banderolą ${ }^{55}$ - odbywało się poprzez wytłoczenie znaku stemplowego na jednej karcie taliii ${ }^{56}$.

Karty przeznaczone do wywozu za granicę oraz karty przeznaczone do przewozu przez obszar państwa co do zasady nie podlegały opodatkowaniu ${ }^{57}$, natomiast od kart przywożonych zza granicy podatek uiszczano równocześnie $\mathrm{z} \mathrm{clem}^{58}$. Urząd celny odnotowywał uiszczenie podatku od kart do gry na deklaracji celnej ${ }^{59}$, a następnie przesyłał karty wraz z deklaracją do urzędu powołanego do stemplowania, który z kolei zaopatrywał każdą kartę w banderolę i stemplował karty według zasad przyjętych dla kart wyprodukowanych w kraju ${ }^{60}$.

Konstrukcja podatku od kart do gry zakładała objęcie zakresem podmiotowym tej daniny jedynie dwóch kategorii podatników, tj. producentów i impor-

$52 \S 9,28$ i 29 rozp. MS z 31.10.1920 r.

${ }^{53}$ Art. 3 ustawy w przedmiocie opłaty stemplowej od kart do gry z $1920 \mathrm{r}$.

${ }^{54}$ Zgodnie z § 19 rozp. MS z 31.10.1920 r. urzędami powołanymi do stemplowania kart były: I Urząd Skarbowy Podatków i Opłat Skarbowych w Warszawie, Główny Urząd Celny we Lwowie, a na obszarze byłej dzielnicy pruskiej Urząd Skarbowy Podatków Pośrednich i Opłat Skarbowych w Poznaniu (do jego utworzenia Główny Urząd Celny w Poznaniu). Od 1922 r. były to: I Urząd Skarbowy Podatków i Opłat Skarbowych w Warszawie, II Urząd Skarbowy Podatków i Opłat Skarbowych w Łodzi, Urząd Skarbowy Akcyz i Monopolów Państwowych w Wilnie, Kasa Skarbowa B we Lwowie oraz Urząd Skarbowy Podatków Pośrednich w Poznaniu (paragraf rozporządzenia Ministra Skarbu z dnia 21 sierpnia 1922 r. zmieniającego niektóre postanowienia rozporządzenia z dnia 31 października 1920 r. w przedmiocie opłaty stemplowej od kart do gry, Dz. U. Nr 74, poz. 674). Zob. rozporządzenie Ministra Skarbu z dnia 15 kwietnia 1923 r. w przedmiocie utworzenia kas skarbowych we Lwowie i w Krakowie, oraz w przedmiocie częściowej zmiany rozporządzenia z dnia 21 sierpnia 1922 r. o opłacie stemplowej od kart do gry (Dz. U. RP Nr 31, poz. 201).

${ }^{55}$ Szczegółowe przepisy dotyczące samych banderoli oraz zasad ich przekazywania wytwórcom kart zawarte zostały w rozp. MS z 31.10.1920 r.

${ }^{56}$ Do ostemplowania przeznaczano asa kier. W sytuacji, gdy nie było asa kier, stempel wytłaczano na innym asie, a w braku asów stemplowano tę kartę, na której uwidoczniona była firma wytwórcy. Zob. § 18 rozp. MS z 31.10.1920 r.

${ }^{57}$ Art. 1 ustawy w przedmiocie opłaty stemplowej od kart do gry z 1920 r. Wyłączenie z opodatkowania miało miejsce wyłącznie wówczas, gdy spełnione zostały warunki określone w przepisach o obrocie towarowym za granicą, bądź w przepisach o przewozie tranzytowym. Zob. § 2-3 rozp. MS z 31.10.1920 r.

${ }^{58}$ Art. 2 ustawy w przedmiocie opłaty stemplowej od kart do gry z $1920 \mathrm{r}$.

${ }^{59}$ Urzędami przeznaczonymi do oclenia kart do gry przywiezionych zza granicy były urzędy celne w Warszawie i we Lwowie, a na obszarze byłej dzielnicy pruskiej Główny Urząd Celny w Poznaniu. Od 1923 r. funkcję tę pełniły również urzędy celne w Łodzi, Poznaniu i Wilnie. Zob. rozporządzenie Ministra Skarbu w dnia 14 maja 1923 r. w przedmiocie stemplowania kart do gry (Dz. U. Nr 54, poz. 380).

${ }^{60} \S 25-26$ rozp. MS z 31.10.1920 r. 
terów kart do gry. Na mocy przepisów przejściowych obowiązek podatkowy ciążył jednak na każdym, kto w dniu 15 listopada 1920 r. posiadał więcej niż dwie talie kart do gry ${ }^{61}$. Stawka podatku od takich kart wynosiła 30 marek od talii, przy czym podatnikom przysługiwało prawo do potrącenia kwot opłaty stemplowej uiszczonej na podstawie przepisów dotychczasowych, obowiązujących w poszczególnych dzielnicach ${ }^{62}$. Analogiczne rozwiązanie zastosowano, rozciągając moc obowiązującą ustawy w przedmiocie opłaty stemplowej od kart do gry na województwa nowogródzkie, poleskie i wołyńskie oraz niektóre powiaty województwa białostockiego ${ }^{63}$, a następnie także na obszar ziemi wileńskiej ${ }^{64}$. Karty nieostemplowane zgodnie z powyższymi przepisami w ogóle nie mogły być dopuszczone do obrotu.

IV. W zakresie opodatkowania kart do gry odmienne regulacje obowiązywały w autonomicznym województwie śląskim. W myśl przepisów ustawy konstytucyjnej zawierającej statut organiczny województwa śląskiego zakres spraw Sejmu Śląskiego w dziedzinie skarbowości, a zwłaszcza stosunek systemu podatkowego śląskiego do systemu podatkowego państwowego miały zostać uregulowane w równobrzmiących ustawach państwowej i śląskiej ${ }^{65}$. Ponieważ zapowiedziane w statucie organicznym rozdzielenie źródeł dochodów nie zostało dokonane przez cały okres istnienia województwa śląskiego, funkcjonowały, przewidziane jako tymczasowo obowiązujące, te ustawy o podatkach i opłatach, które obowiązywały na tym obszarze 1 stycznia 1919 r., jak również ustawy o podatkach i opłatach wprowadzonych później przez rządy niemiecki, pruski lub czeski i komisje międzysojusznicze, o ile ich ważność została utrzymana ustawą Sejmu Śląskiego ${ }^{66}$. Jednocześnie statut

${ }^{61}$ § 32-33 rozp. MS z 31.10.1920 r. Zob. także rozporządzenie Ministra Skarbu z dnia 16 listopada 1920 r. w przedmiocie przedłużenia terminu dodatkowego stemplowania kart do gry (Dz. U. RP Nr 108, poz. 713), rozporządzenie Ministra b. Dzielnicy Pruskiej z dnia 25 listopada 1920 r. w przedmiocie terminu dodatkowego ostemplowania kart do gry (Dz. U. RP Nr 110, poz. 731).

62 Art. 20 ustawy w przedmiocie opłaty stemplowej od kart do gry z $1920 \mathrm{r}$.

${ }^{63}$ Zob. rozporządzenie Ministra Skarbu z dnia 6 lipca 1921 r. w przedmiocie wykonania rozporządzenia Rady Ministrów z dnia 2 czerwca 1921 r. w przedmiocie rozciągnięcia mocy obowiązującej ustaw z dnia 6 lipca 1920 r. i z dnia 18 marca 1921 r. o opłacie stemplowej od kart do gry na województwa: nowogródzkie, poleskie i wołyńskie oraz powiaty grodzieński, białowieski i wołkowski województwa białostockiego (Dz. U. RP Nr 67, poz. 437) oraz rozporządzenie Ministra Skarbu z dnia 21 września 1921 r. w przedmiocie przedłużenia terminu zgłoszenia i złożenia kart do gry celem dodatkowego opodatkowania na obszarze województw: nowogródzkiego, poleskiego i wołyńskiego oraz powiatów: grodzieńskiego, białowieskiego i wołkowyskiego województwa białostockiego (Dz. U. RP Nr 80, poz. 552).

${ }^{64}$ Zob. § 3 rozporządzenia Ministra Skarbu z dnia 21 sierpnia 1922 r. zmieniającego niektóre postanowienia rozporządzenia z dnia 31 października 1920 r. w przedmiocie opłaty stemplowej od kart do gry (Dz. U. Nr 74, poz. 674).

${ }^{65}$ Art. 5 ustawy konstytucyjnej z dnia 15 lipca 1920 r. zawierającej statut organiczny Województwa Śląskiego (Dz. U. RP Nr 73, poz. 497, z późn. zm.).

${ }^{66}$ Szerzej zob. Z. Hojka, Skarbowość, [w:] Województwo śląskie (1922-1939). Zarys monograficzny, red. F. Serafin, Katowice 1996, s. 392-393. Na temat przyczyn nieuchwalenia ramowej 
organiczny przewidywał, że w województwie śląskim obowiązywać będą te podatki i opłaty, które zostały jednolicie uregulowane przez ustawy państwowe na całym terenie Rzeczypospolitej i których moc obowiązująca rozciąga się także na terytorium Śląska ${ }^{67}$.

W zakresie podatku od kart do gry na Śląsku obowiązywała niemiecka ustawa o opodatkowaniu kart do gry z 10 września 1919 r. ${ }^{68}$ Zgodnie z jej przepisami talie kart przeznaczone do użytku w kraju podlegały opodatkowaniu podatkiem akcyzowym (podatkiem od talii kart). Danina ta expressis verbis została zatem zaliczona do akcyz. Stawka podatku miała charakter kwotowy i wynosiła 2 marki od każdej talii, przy czym podatek obniżano o połowę w odniesieniu do talii zawierających do 24 kart, zaś podwyższano o połowę w przypadku talii zawierających ponad 48 kart. Ze względu na powyższą konstrukcję na podatnikach ciążył obowiązek informowania organu podatkowego o liczbie kart w talii.

W 1923 r., na mocy aktów prawa śląskiego, zrównano stawkę podatku od kart do gry pobieranego na postawie ustawy niemieckiej ze stawką obowiązującą w Rzeczypospolitej Polskiej, wskazując, iż wynosi ona 300 marek polskich od taliii ${ }^{69}$. Jednocześnie zastrzeżono, że dopóki w górnośląskiej części województwa śląskiego ustawowym środkiem płatniczym będzie waluta niemiecka, kwotę podatku wolno płacić w markach niemieckich ${ }^{70}$.

W myśl rozporządzenia Rady Wojewódzkiej opodatkowaniu podlegały wszelkie karty, których można było użyć do gry, bez względu na ich formę oraz liczbę kart tworzących talię, w tym również karty sprowadzane z zagra-

ustawy skarbowej szerzej zob. J. Ciągwa, Wpływ centralnych organów Drugiej Rzeczypospolitej na ustawodawstwo śląkie w latach 1922-1939, Katowice 1979, s. 54-57 oraz powoływana tam literatura.

${ }^{67}$ Uchwalone przez Sejm RP podatki i opłaty miały wejść w miejsce analogicznych podatków i opłat poprzednio obowiązujących na Śląsku.

${ }^{68}$ Spielkartensteuergesetz vom 10 September 1919, Reichs-Gesetzblatt 1919, Nr 7048, s. $1643-$ -1652 .

${ }^{69}$ Art. 1 ustawy z dnia 6 lutego 1923 r. w przedmiocie regulowania podatków spożywczych (Dz. Ust. Śl. Nr 9, poz. 58) oraz art. 1 rozporządzenia Rady Wojewódzkiej z dnia 20 lutego 1923 r. w przedmiocie ujednostajnienia podatku od kart do gry (Dz. Ust. Śl. Nr 11, poz. 72). Śląska Rada Wojewódzka była naczelnym organem administracyjnym województwa śląskiego, któremu przysługiwały uprawnienia m. in. w zakresie skarbowości. Szerzej zob. E. Kaznowska, Kompetencje Śląskiej Rady Wojewódzkiej - regulacja prawna oraz praktyka (1922-1939), [w:] Z dziejów prawa, red. A. Lityński, Katowice 1996, s. 174-185.

${ }^{70}$ Konwencja niemiecko-polska dotycząca Górnego Śląska, podpisana w Genewie dnia 15 maja 1922 r. (Dz. U. RP Nr 44, poz. 371) stanowiła, że przez okres nie mogący przekroczyć 15 lat marka niemiecka pozostanie na przejętym przez Polskę obszarze wyłącznym prawnym środkiem płatniczym. Dodatkowy przepis przewidywał jednak, że na podstawie porozumienia między rządem polskim a niemieckim marka polska będzie mogła być prawnym środkiem płatniczym przed upływem wskazanego okresu. Szerzej na temat sytuacji walutowej na Górnym Śląsku zob. Z. Karpiński, op. cit., s. 40-42; W. Marcoń, Unifikacja województwa śląskiego z II Rzeczpospolita, Toruń 2007, s. 97-99 i 125-126. 
nicy ${ }^{71}$. Stemplowanie odbywało się przez wytłoczenie znaku stemplowego na jednej talii kart ${ }^{72}$, a zgłaszający karty do opodatkowania zobowiązany był do naklejenia na talię polskiej banderoli i złożenia deklaracji podatkowej. Obowiązek podatkowy ciążył na przedsiębiorcach oraz osobach prywatnych, które w momencie wejścia w życie rozporządzeń Rady Wojewódzkiej posiadały więcej niż dwie talie kart do gry ${ }^{73}$, przy czym dodatkowemu opodatkowaniu nie podlegały karty sprowadzone z Rzeczypospolitej, o ile były opatrzone polskim znakiem stemplowym i banderolą ${ }^{74}$. Warto także dodać, że przepisy niemieckiej ustawy o podatku od kart do gry podlegały nowelizacjom w związku z szalejącą hiperinflacją. W grudniu $1923 \mathrm{r}$. stawkę podatku podwyższono do 100000 marek polskich od talii ${ }^{75}$, a 4 miesiące później dokonano jej przeliczenia na 0,5 franka złotego ${ }^{76}$. Dochód z podatku od gier pobieranego na obszarze województwa śląskiego wpływał do skarbu śląskiego, który z kolei był zobowiązany do odprowadzenia części swoich dochodów do skarbu państwowego w ramach tzw. tangenty. Wypada także odnotować, że na terenie województwa śląskiego obowiązywała wspomniana już ustawa z dnia 6 czerwca 1924 r. o opłacie od kart do gry na rzecz Polskiego Czerwonego Krzyżza ${ }^{77}$.

V. Istotne zmiany $\mathrm{w}$ zakresie opodatkowania kart do gry wprowadziła ustawa z $1931 \mathrm{r}$. o opłacie od kart do gry ${ }^{78}$, która zastapiła polską ustawę z 1920 r. oraz obowiązującą na Śląsku niemiecką ustawę o podatku od kart do gry z 1919 r. Opodatkowaniu nadal podlegały karty wyprodukowane w Polsce oraz sprowadzone z zagranicy ${ }^{79}, \mathrm{z}$ tym że wysokość stawki podatku uza-

${ }^{71} \S 1$ rozporządzenia z dnia 24 lutego 1923 r. celem wykonania rozporządzenia Rady Wojewódzkiej z dnia 20 lutego 1923 r. w przedmiocie opodatkowania kart do gry (Dz. Ust. Śl. Nr 11, poz. 75).

72 Podobnie jak na pozostałym obszarze Polski do ostemplowania co do zasady przeznaczano asa kierowego. Urzędem właściwym w zakresie stemplowania była Kasa Skarbowa w Katowicach.

${ }^{73}$ Art. 2 rozporządzenia Rady Wojewódzkiej z dnia 20 lutego 1923 r. w przedmiocie ujednostajnienia podatku od kart do gry (Dz. Ust. Śl. Nr 11, poz. 72).

${ }^{74}$ Stawka podatku podlegała pomniejszeniu o podatek zapłacony na postawie ustawy niemieckiej pod warunkiem, że karty były opatrzone znakiem stemplowym Kasy Skarbowej w Katowicach. Potrąceniu nie ulegała natomiast kwota uiszczona na rzecz byłych władz niemieckich.

75 § 1 rozporządzenia Rady Ministrów z dnia 3 grudnia 1923 r. w sprawie podatku od kart do gry na obszarze górnośląskiej części województwa śląskiego (Dz. U. RP Nr 127, poz. 1046).

76 § 1 rozporządzenia Rady Ministrów z dnia 3 marca 1924 r. w sprawie zastosowania stałej jednostki do podatku od kart do gry na górnośląskiej części województwa śląskiego (Dz. U. RP $\mathrm{Nr} 27$, poz. 275).

77 Zob. W. Marcoń, op. cit., s. 128.

${ }^{78}$ Ustawa z dnia 18 marca 1931 r. o opłacie od kart do gry (Dz. U. RP Nr 27, poz. 171), dalej jako: ustawa o opłacie od kart do gry.

${ }^{79}$ Zgodnie z § 2 rozporządzenia Ministra Skarbu z dnia 31 marca 1931 r. w sprawie wykonania ustawy z dnia 18 marca 1931 r. o opłacie od kart do gry (Dz. U. Nr 32, poz. 234, z późn. zm.) karty do gry przeznaczone do wywozu za granicę lub na obszar Wolnego Miasta Gdańska nie podlegały opodatkowaniu pod warunkiem, że przy wywozie zachowany został określony tryb postępowania. 
leżniona była od dwóch czynników. Po pierwsze od tego, czy karty zostały wytworzone z kartonu papierowego, czy z materiałów bardziej kosztownych, po drugie - od liczby kart w talii. Stawka podatku od kart sporządzonych z kartonu papierowego wynosiła 1zł 30 gr od talii liczącej do 36 kart oraz 2 zł od talii składającej się z więcej niż 36 kart. Karty wyprodukowane z innych materiałów, np. cellonu, płótna, jedwabiu, masy celuloidowej lub aluminiowej, były opodatkowane stawką w wysokości $10 \mathrm{zl,} \mathrm{niezależnie} \mathrm{od} \mathrm{liczby} \mathrm{kart}$ w talii ${ }^{80}$. W 1939 r. stawki te podwyższono odpowiednio do: $1 \mathrm{zł} 70$ gr, 2 zł 60 gr oraz $15 \mathrm{zt}^{81}$.

Podlegały opodatkowaniu wszelkie karty, których można było użyć do gry, bez względu na ich formę oraz rodzaj znaków na nich zamieszczonych ${ }^{82}$. W związku z powyższym ścisłej reglamentacji podlegała zarówno ich produkcja, jak i sprzedaż ${ }^{83}$. Dodać należy, że ustawa z 1931 r. statuowała nie tylko zakaz sprzedaży, ale także nabywania kart do gry nieobanderolowanych, używanych oraz niezaopatrzonych w stempel, jak również zakaz używania kart nieposiadających stempla ${ }^{84}$.

Podatek od kart produkowanych w Polsce płacony był gotówką przy dopuszczeniu kart do obrotu, zaś dowodem jego uiszczenia były stempel urzędowy oraz banderola. Od kart przywożonych z zagranicy podatek pobierano wraz z cłem, a od kart sprowadzanych z obszaru Wolnego Miasta Gdańska - w chwili zgłoszenia w urzędzie odbiorczym w trybie przepisanym do postępowania przekazowego ${ }^{85}$. Ustawa przewidywała również, że należność przypadająca $\mathrm{z}$ tytułu podatku od kart do podlegała zaspokojeniu z kart z pierwszeństwem przed wszystkimi innymi przywilejami i obciążeniami oraz mogła być wyegzekwowana bez względu na jakiekolwiek prawa osób trzecich ${ }^{86}$.

Wysokość specjalnej opłaty na rzecz Polskiego Czerwonego Krzyża, podobnie jak wysokość stawek podatkowych, była uzależniona od liczby kart w talii oraz materiału, z jakiego karty zostały wytworzone. Od talii zawierającej do 36 kart pobierano 40 gr, od talii liczącej ponad 36 kart 60 gr, natomiast od kart wyrabia-

${ }^{80}$ Art. 2 ustawy o opłacie od kart do gry. Wątpliwości co do materiału z jakiego zostały wyprodukowane karty rozstrzygał urząd właściwy w zakresie stemplowania kart, w razie potrzeby po zasięgnięciu opinii rzeczoznawców.

${ }^{81}$ Art. 2 ustawy o opłacie od kart do gry w brzmieniu nadanym ustawą z dnia 25 maja 1939 r. o zmianie ustawy o opłacie od kart do gry (Dz. U. RP Nr 50, poz. 318).

${ }^{82} \S 1$ rozporządzenia Ministra Skarbu z dnia 31 marca 1931 r. w sprawie wykonania ustawy z dnia 18 marca 1931 r. o opłacie od kart do gry (Dz. U. Nr 32, poz. 234, z późn. zm.).

${ }^{83} \mathrm{Na}$ temat warunków produkcji kart do gry oraz funkcjonujących w tym okresie fabryk kart szerzej zob. E. Werner, Optata od kart do gry, „Czasopismo Skarbowe” 1931, nr 7, s. 375-377.

${ }^{84}$ Art. 6 ust. 3 ustawy o opłacie od kart do gry.

${ }^{85}$ Art. 3 ustawy o opłacie od kart do gry. Do odprawy celnej kart do gry przywożonych z zagranicy oraz z obszaru Wolnego Miasta Gdańska upoważniony był jedynie urząd celny w Warszawie. Stemplowanie przeprowadzał Urząd Opłat Stemplowych w Warszawie.

${ }^{86}$ Art. 4 ustawy o opłacie od kart do gry. 
nych z materiałów innych niż karton papierowy $5 \mathrm{z}^{87}$. Z powyższej konstrukcji zrezygnowano dopiero w 1939 r., przyjmując zasadę, że stowarzyszenie Polski Czerwony Krzyż otrzymuje 50\% wpływów z tytułu podatku od kart do gry ${ }^{88}$. Jak już zaznaczono, podatek od kart do gry, podobnie jak inne podatki obrotowe, historycznie rozwinął się razem z opłatami stemplowymi. Wyrazem genetycznego związku tej daniny z opłatami stemplowymi był brak jednolitej konwencji terminologicznej $\mathrm{w}$ aktach prawnych oraz różnice $\mathrm{w}$ kwalifikacji wpływów z tego źródła w poszczególnych budżetach ${ }^{89}$. W okresie dwudziestolecia międzywojennego danina pobierana na rzecz państwa od kart do gry w języku prawnym była określana mianem „opłaty stemplowej” bądź „opłaty”, zdecydowanie rzadziej używano pojęć „,opodatkowanie"90 i „podatek" 91. W doktrynie istniała natomiast zgodność co do tego, że w ujęciu teoretycznym był to podatek. W szczególności wskazywano, że był to podatek konsumpcyjny ${ }^{92}$, pośredni ${ }^{93}$, podatek od wyrobu przedmiotu zbytku ${ }^{94}$, danina o charakterze akcyzy ${ }^{95}$, podatek od rozrywki ${ }^{96}$, czy szczególny rodzaj podatku obrotowego, tj. podatku od spekulacji i gry ${ }^{97}$.

${ }^{87}$ Art. 12 ustawy o opłacie od kart do gry w wersji pierwotnej.

${ }^{88}$ Art. 10 ust. 2 ustawy o opłacie od kart do gry w brzmieniu nadanym ustawą z dnia 25 maja 1939 r. o zmianie ustawy o opłacie od kart do gry (Dz. U. RP Nr 50, poz. 318).

${ }^{89} \mathrm{~W}$ preliminarzach budżetowych danina od kart do gry co do zasady była kwalifikowana jako opłata, jedynie w latach 1927-1930 zaliczana była do akcyz. Zob. I. Weinfeld, Skarbowość polska, Warszawa 1931, s. 230 oraz idem, Daniny. Podatki, opłaty, cła i akcyzy skarbowości polskiej, Warszawa 1937, s. 236.

${ }^{90}$ Zob. rozporządzenie Ministra Skarbu z dnia 21 września 1921 r. w przedmiocie przedłużenia terminu zgłoszenia i złożenia kart do gry celem dodatkowego opodatkowania na obszarze województw: nowogródzkiego, poleskiego i wołyńskiego oraz powiatów: grodzieńskiego, białowieskiego i wołkowyskiego województwa białostockiego (Dz. U. RP Nr 80, poz. 552). Ustawa o opłacie od kart do gry na rzecz Polskiego Towarzystwa Czerwonego Krzyża posługiwała się zarówno pojęciem ,opłaty”, jak i ,podatku”.

${ }^{91}$ Ze względu na to, że na Śląsku obowiązywała niemiecka ustawa z 1919 r. o opodatkowaniu kart do gry, pojęciem ,podatek” posługiwano się w aktach polskich odnoszących się do tej daniny. Zob. rozporządzenie Rady Ministrów z dnia 3 grudnia 1923 r. w sprawie podatku od kart do gry na obszarze górnośląskiej części województwa śląskiego (Dz. U. RP Nr 127, poz. 1046) oraz rozporządzenie Rady Ministrów z dnia 3 marca 1924 r. w sprawie zastosowania stałej jednostki do podatku od kart do gry na górnośląskiej części województwa śląskiego (Dz. U. RP Nr 27, poz. 275). Nazwa podatek od kart do gry występowała również na gruncie przepisów karnych skarbowych. Zob. art. 124 Ustawy Karnej Skarbowej z dnia 2 sierpnia 1926 r. (Dz. U. RP Nr 105, poz. 609, z późn. zm.); art. 1 pkt 9 ustawy karnej skarbowej z dnia 18 marca 1932 r. (Dz. U. Nr 34, poz. 355, z późn. zm.).

92 Zob. E. Werner, op. cit., s. 374.

93 Zob. W. Grabowski, op. cit., Podatki pośrednie, [w:] Odrodzona skarbowość polska. Zarys historyczny, Warszawa 1931, s. 89.

94 Zob. E. Taylor, Polityka skarbowa ..., s. 291.

95 Zob. I. Weinfeld, Skarbowość..., s. 230; D. Mączyński, O akcyzie w Polsce w latach 1918-1939, „Czasopismo Prawno-Historyczne” 2005, z. 1, t. LVII, s. 292 oraz powoływana tam literatura.

${ }^{96}$ Zob. S. Głąbiński, Nauka skarbowości. Wydanie nowe (trzecie), Warszawa-Lwów 1925, s. 444.

${ }^{97}$ Zob. S. Głąbiński, Nauka skarbowości z dodatkiem..., s. 466. 
Przyjmując współcześnie stosowane kryteria klasyfikacji podatków, daninę od kart do gry należałoby określić jako podatek państwowy, który w całości stanowił dochód skarbu państwowego ${ }^{98}$. Ponadto był to podatek zwyczajny, rzeczowy, obligatoryjny i pośredni. Ponieważ obowiązek podatkowy co do zasady powstawał $\mathrm{w}$ momencie dopuszczenia kart do obrotu, a nie $\mathrm{w}$ chwili uzyskania przychodu z tego tytułu, uzasadniony wydaje się wniosek, że był to jednofazowy podatek obrotowy obciążający produkcję oraz import kart do gry.

Należy zauważyć, że na gruncie normatywnym pojęcie opłaty stosowane było także w odniesieniu do specjalnego świadczenia na rzecz Polskiego Towarzystwa Czerwonego Krzyża. W literaturze przedmiotu posługiwano się w tym wypadku określeniami „opłata”, „dopłata” lub „nadzwyczajny dodatek" $" 99$, choć nie była to ani opłata, ani dopłata w rozumieniu teoretycznym ${ }^{100}$. Świadczenie na rzecz Polskiego Towarzystwa Czerwonego Krzyża (od 1927 r. Polskiego Czerwonego Krzyża) ustalane było jednostronnie przez państwo w drodze ustawy, miało charakter obligatoryjny i przymusowy, a obowiązek jego uiszczenia powstawał równocześnie z obowiązkiem podatkowym w podatku od gier. Podmiotem uprawnionym do jego otrzymania nie był jednak związek publicznoprawny lecz działające pod protektoratem Prezydenta Rzeczypospolitej Polskiej stowarzyszenie o szczególnym znaczeniu społecznym ${ }^{101}$.

Bezpośrednio po zakończeniu II wojny światowej przywrócono przedwojenny system podatkowy, w tym podatek od kart do gry, który funkcjonował do 26 marca 1947 r. ${ }^{102}$ Podkreślić należy, że ustawa o opłacie od kart do gry została uchylona $\mathrm{w}$ ramach procesu porządkowania akcyz, zaś produkcja, import oraz renowacja kart do gry zostały objęte podatkiem akcyzowym ${ }^{103}$.

${ }^{98}$ Art. 10 ustawy o opłacie od kart do gry wyraźnie stanowił, że karty te nie mogły być opodatkowane na rzecz związków komunalnych, ani w postaci podatków samoistnych, ani w postaci dodatków do podatku.

${ }^{99}$ Zob. E. Werner, op. cit., s. 374; I. Weinfeld, Daniny. Podatki..., s. 237; E. Taylor, Polityka skarbowa..., s. 291.

${ }^{100} \mathrm{Na}$ temat cech konstytutywnych opłat i dopłat w ujęciu teoretycznym zob. J. Gliniecka, Opłaty publiczne w Polsce. Analiza prawna i funkcjonalna, Bydgoszcz-Gdańsk 2007; I. CzajaHliniak, Prawnofinansowa instytucja dopłat jako forma pozapodatkowych danin publicznych, Kraków 2006 oraz powoływana tam literatura.

${ }^{101}$ Stowarzyszenie „Polski Czerwony Krzyż” było w okresie międzywojennym jedynym stowarzyszeniem na obszarze Polski działającym za zasadach konwencji genewskiej o polepszeniu losu chorych i rannych w armiach czynnych z dnia 6 lipca 1906 r. (Dz. U. RP z 1927 r. Nr 28, poz. 225) oraz konwencji dotyczącej praw i zwyczajów wojny lądowej podpisanej w Hadze w dniu 18 października 1907 r. (Dz. U. RP z 1927 r. Nr 21, poz. 160 i 161), któremu przysługiwało prawo używania znaku i nazwy Czerwonego Krzyża. Zob. rozporządzenie Prezydenta Rzeczypospolitej z dnia 1 września 1927 r. o Stowarzyszeniu „Polski Czerwony Krzyż” (Dz. U. RP Nr 79, poz. 688).

102 Szerzej zob. L. Adam, Prawo finansowe, Warszawa-Wrocław 1965, s. 35-36.

${ }^{103}$ Dekret z dnia 3 lutego 1947 r. Prawo akcyzowe (Dz. U. Nr 29, poz. 122, sprost. Dz. U. z 1947 r. Nr 70, poz. 436). 
Zasady opodatkowania w zasadzie nie uległy zmianie, wysokość podatku nadal była uzależniona od liczby kart w talii oraz materiału, $\mathrm{z}$ którego karty zostały wytworzone, natomiast dowodem uiszczenia akcyzy były stempel i banderola ${ }^{104}$. W miarę przeprowadzanych zmian ustrojowo-gospodarczych daniny znane $\mathrm{z}$ okresu międzywojennego zmieniały swoją treść, stając się skutecznym narzędziem realizacji politycznych celów państwa socjalistycznego. W ramach tego procesu podatek akcyzowy został włączony do podatku obrotowego $^{105}$, a produkcję i import kart do gry opodatkowano podatkiem obrotowym $^{106}$. Po zmianie ustroju politycznego i przywróceniu podatku akcyzowego karty do gry objęto akcyzą ${ }^{107}$, która była pobierana do końca lutego 2009 r. ${ }^{108}$

VI. Opodatkowanie kart do gry ma zatem w Polsce bogate tradycje. Analiza kolejnych regulacji historycznych prowadzi do wniosku, że pierwotna konstrukcja prawna tej daniny, przyjęta w konstytucji sejmowej z 1775 r., w zasadniczym kształcie przetrwała do końca okresu obowiązywania ustawy o opłacie od kart do gry, czyli do 1947 r. Znalazła również odzwierciedlenie w prawie akcyzowym z $1947 \mathrm{r}$. Na uwagę zasługuje obowiązujący w dwudziestoleciu międzywojennym obowiązek odprowadzania dodatkowych należności na rzecz Polskiego Czerwonego Krzyża. Normatywne powiązanie działalności gospodarczej dotykającej sfery szeroko rozumianego hazardu oraz opodatkowania takiej działalności z obowiązkiem świadczenia na cele społecznie użyteczne stanowi cechę rozwiązań prawnofinansowych, która widoczna jest również we współczesnych regulacjach.

Zgodnie z osiemnastowiecznym pierwowzorem, przez cały okres funkcjonowania podatku od kart do gry przedmiot opodatkowania stanowiła produkcja oraz import tego rodzaju kart, obowiązek podatkowy powstawał z chwila ich wprowadzenia do obrotu, a dowodem uiszczenia podatku był stempel wy-

104 Szczegółowe przepisy dotyczące zasad produkcji kart do gry, uiszczenia podatku oraz nadzoru akcyzowego zostały zawarte w rozporządzeniu Ministra Skarbu z dnia 5 grudnia 1947 r. w sprawie częściowego wykonania prawa akcyzowego oraz dekretu z dnia 3 lutego 1947 r. o postępowaniu akcyzowym, wydanego co do $§ 21$ i ust. 1-3) w porozumieniu z Ministrem Przemysłu i Handlu (Dz. U. z 1948 r. Nr 8, poz. 58).

${ }^{105} \mathrm{~W}$ systemie reglamentacji cen dalsze odrębne funkcjonowanie akcyz stało się anachronizmem. Szerzej zob. H. Reniger, Podatki z gospodarki nieuspolecznionej, [w:] Prawo finansowe, red. L. Kurowski, Warszawa 1955, s. 385-386.

${ }^{106}$ Art. 8 dekretu z dnia 25 października 1948 r. o podatku obrotowym (Dz. U. Nr 52, poz. 413, z późn. zm.) oraz rozporządzenia Ministra Skarbu z dnia 8 marca 1949 r. w sprawie wykonania dekretu z dnia 25 października 1948 r. o podatku obrotowym (Dz. U. Nr 17, poz. 108, z późn. zm.).

107 Zob. załącznik nr 6 do ustawy z dnia 8 stycznia 1993 r. o podatku od towarów i usług (Dz. U. Nr 11, poz. 50, z późn. zm.) oraz załącznik nr 1 do ustawy z dnia 23 stycznia 2004 r. o podatku akcyzowym (Dz. U. Nr 29, poz. 257, z późn. zm.).

${ }^{108}$ Ustawa z dnia 6 grudnia 2008 r. o podatku akcyzowym (Dz. U. Nr 3, poz. 11) nie przewidywała już akcyzy od kart do gry. 
bijany na poszczególnych taliach. Opodatkowaniu podlegała talia kart jako całość, zaś stawki miały charakter kwotowy.

W toku ewolucji regulacji prawnopodatkowych zmianom ulegały natomiast kryteria kształtowania ciężaru podatkowego. W okresie I Rzeczypospolitej wysokość podatku była uzależniona od typu kart (francuskie lub polskie) oraz od tego, czy zostały one wytworzone w kraju, czy sprowadzone z zagranicy. W XIX w., na skutek przemian społeczno-obyczajowych, karty polskie wyszły z użycia, lecz pojawiły się nowe rodzaje gier, do których stosowano odmienne talie, np. taroki. Ponadto karty zaczęto wytwarzać z nieznanych dotąd materiałów, takich jak masa celuloidowa. Wskazane zmiany kulturowe i technologiczne znalazły odzwierciedlenie w kryteriach różnicowania obciążenia podatkowego stosowanych w dwudziestoleciu międzywojennym. Stawka podatku była wówczas uzależniona od liczby kart w talii oraz od materiału, z którego wyprodukowano karty.

Konkludując, należy stwierdzić, że podatek od kart do gry, historycznie związany z opłatami stemplowymi, był jednofazowym podatkiem obrotowym obciążającym produkcję oraz import tego rodzaju kart. Uzasadnienia dla odrębnego opodatkowania obrotu kartami do gry należy upatrywać w charakterze samych kart, które powszechnie uznawano za przedmiot zbytkowny, szkodliwy, a w kontekście gier hazardowych nawet niebezpieczny. Podatek od kart do gry można także zaliczyć do podatków od konsumpcji przejawiającej się w posiadaniu przedmiotów zbytkowych. Odstępstwo od powyższego modelu opodatkowania w formie podatku o charakterze akcyzy stanowił jedynie, wprowadzony w okresie Księstwa Warszawskiego, częściowy monopol fiskalny państwa. 